\title{
Frequencies of genes for coat colour and horns in Nordic cattle breeds
}

\author{
Juha KANTANEN ${ }^{a}$, Ingrid Olsaker $^{\mathrm{b}}$, Klaus BRUSGAARD ${ }^{\mathrm{c}}$, \\ Emma EyTHORSDOTTIR ${ }^{d}$, Lars-Erik HolM ${ }^{c}$, Sigbjørn LIEN ${ }^{\mathrm{e}}$, \\ Birgitta DANEll ${ }^{\mathrm{f}}$, Stefan AdALSTEINSSON ${ }^{\mathrm{g}}$
}

a Animal Production Research, Agricultural Research Centre of Finland (MTT), 31600 Jokioinen, Finland

b Department of Morphology, Genetics and Aquatic Biology, The Norwegian College of Veterinary Science, P.O. Box 8146 Dep., 0033 Oslo, Norway

${ }^{c}$ Department of Animal Breeding and Genetics, Danish Institute of Agricultural Sciences, P.O. Box 50, 8830 Tjele, Denmark

d Agricultural Research Institute, Keldnaholt, 112 Reykjavik, Iceland

e Department of Animal Science, Agricultural University of Norway, P.O. Box 5025, $1432 \AA$ As, Norway

${ }^{f}$ Department of Animal Breeding and Genetics, Swedish University of Agricultural Sciences, Box 7023, 75007 Uppsala, Sweden

$g$ The Nordic Gene Bank for Farm Animals, Department of Animal Science, Agricultural University of Norway, P.O. Box 5025, $1432 \AA$ s, Norway.

Present address: Sudurgata 24, 101 Reykjavik, Iceland

(Received 10 February 2000; accepted 26 September 2000)

\begin{abstract}
Gene frequencies of coat colour and horn types were assessed in 22 Nordic cattle breeds in a project aimed at establishing genetic profiles of the breeds under study. The coat colour loci yielding information on genetic variation were: extension, agouti, spotting, brindle, dun dilution and colour sided. The polled locus was assessed for two alleles. A profound variation between breeds was observed in the frequencies of both colour and horn alleles, with the older breeds generally showing greater variation in observed colour, horn types and segregating alleles than the modern breeds. The correspondence between the present genetic distance matrix and previous molecular marker distance matrices was low $(r=0.08-0.12)$. The branching pattern of a neighbour-joining tree disagreed to some extent with the molecular data structure. The current data indicates that $70 \%$ of the total genetic variation could be explained by differences between the breeds, suggesting a much greater breed differentiation than typically found at protein and microsatellite loci. The marked differentiation of the cattle breeds and observed disagreements with the results from the previous molecular data in the topology of the phylogenetic trees are most likely a result of selection on phenotypic characters analysed in this study.
\end{abstract}

cattle / coat colour / horns

\footnotetext{
* Correspondence and reprints

E-mail: juha.kantanen@mtt.fi
} 
Résumé - Fréquences génétiques pour la couleur de la robe et la présence de cornes chez des races de bovins nordiques. Dans le cadre d'un projet visant à établir leurs profils génétiques, on a estimé les fréquences génétiques à des locus gouvernant la couleur de la robe et la présence de cornes chez 22 races de bovins nordiques. Les locus informatifs pour évaluer la variation génétique étaient extension, agouti, spotting, brindle, dun dilution, colour sided et polled. On a mis en évidence une importante variation des fréquences de ces gènes entre les races, et les races les plus anciennes montraient généralement plus de variation que les races modernes. La correspondance entre la matrice des distances génétiques obtenue dans cette étude et celle trouvée précédemment à partir de marqueurs moléculaires était faible $(r=0,08-0,12)$. Le dendrogramme obtenu à partir de la méthode du «neighbour-joining» comportait certaines différences avec celui déjà construit à l'aide de marqueurs moléculaires. Notre étude indique que $70 \%$ de la variation génétique totale pourrait être due aux différences entre les races, suggérant ainsi une différenciation entre races plus forte que celle anticipée à partir des locus de protéines ou des microsatellites. Ces différences entre les présents résultats et ceux obtenus à partir d'autres marqueurs sont vraisemblablement dues à la sélection qui a été menée sur les caractères phénotypiques correspondant aux locus analysés dans ce travail.

bovins / couleur / robe / cornes

\section{INTRODUCTION}

The genetic basis for coat colour in cattle has been intensively studied in the past. Significant contributions to the field have been made by Wright [26], Bogart and Ibsen [7], Berge [4], Lauvergne [14], Searle [22], Olson and Willham [20] and Adalsteinsson et al. [2]. In addition, the extension locus that corresponds to the melanocyte-stimulating hormone receptor gene $(M c 1 r)$ [17] was recently studied at the molecular level in black, brown and red cattle [13]. At least seven different loci have been identified as being involved in the phenotypic determination of the colour traits in cattle. However, only a few studies have provided breed-specific allele frequency information for coat colour and horn morphology loci in cattle.

Calculation of genetic distances from data of neutral molecular markers, e.g. [12], such as microsatellites, can provide useful information for the management of rare breeds. Genetically closely related breeds can be used in intercrossing schemes, where the reduction of inbreeding and its detrimental effects in endangered breeds are important aims. However, the maintenance of traditional colour types, which were determined when herd books were established about a hundred years ago, is important for the preservation of the cultural historical value of endangered native breeds. Therefore, breed similarities and differences in genetic variation at coat colour loci can also be considered when breeds are chosen for intercrossing schemes.

We applied allele frequencies for coat colour and horns in order to assess genetic diversity of 22 North European cattle breeds. The results presented here are part of a larger project on the estimation of genetic profiles of Nordic cattle breeds. In addition to the information on colours and on presence of horns, gene frequencies of blood groups, serum proteins, milk proteins and microsatellites have been assessed [12]. 


\section{MATERIALS AND METHODS}

\subsection{Information on breeds}

The Danish, Finnish, Icelandic, Norwegian and Swedish cattle breeds studied were:

(i) 15 native breeds: Jutland Breed, Danish Black-Pied 1965, Danish Red 1970, Eastern Finncattle, Northern Finncattle, Western Finncattle, Icelandic Cattle, Blacksided Troender and Nordland Cattle, Doela Cattle, Eastern Red Polled, Telemark Cattle, Western Fjord Cattle, Western Red Polled, Swedish Mountain Cattle and Swedish Red Polled. Danish BlackPied 1965 and Red Danish 1970 are remnants of old Danish Black-Pied and Red Danish types as they existed in 1965 and 1970, respectively, before crossbreeding with commercial Black-Pied and Red breeds commenced.

(ii) Two older imported breeds: Danish Jersey and Danish Shorthorn. These breeds were imported in the 19th century from Great Britain. Studied Jersey animals were of the original Danish type and therefore not crossbred with American Jersey.

(iii) Five modern commercial breeds: Finnish Ayrshire, Finnish HolsteinFriesian, Norwegian Cattle (NRF), Swedish Red and White Cattle (SRB) and Swedish Black and White Cattle (SLB).

A short description of the individual breeds under study is given in Table I, due to the obvious link between important breed characteristics and the traits dealt with in the present study. More information is provided elsewhere $[8,12$, 23]. The numbers of animals studied (ranging from 8 to 94 animals per breed, a total of 854 animals) are given in Table III.

\subsection{Data collection and statistical analysis}

In the present study, gene frequencies at the six coat colour loci extension $(E)$, agouti $(A)$, spotting $(S)$, brindle $(B R)$, dun ditution $(D)$ and colour sided (CS) were studied (see [2] and references within). An overview of the colour loci in the present study, with number of alleles and their dominance/epistasis relationships, is given in Table II.

At the $E$-locus, three alleles are found: $E^{\mathrm{D}}$, dominant, producing dominant black; $E^{+}$, intermediate, producing recessive black; and $E^{\mathrm{e}}$, recessive, producing red when homozygous [2]. Two alleles are found at the $A$-locus [2]: $A^{\mathrm{b}}$, dominant, producing brown colour in $E^{+} /-$animals, and $A^{\mathrm{a}}$, recessive, producing recessive black in $E^{+} /-$animals when homozygous. The $A^{\mathrm{b}}$ allele is completely suppressed by the $E^{\mathrm{D}}$ allele, because the production of dominant black pigment is not controlled by the $A$-alleles. $A^{\mathrm{b}}$ shows a full effect in recessive black, $E^{+} /-$, animals, where it can interfere with the synthesis of the black pigment, and switch it from black to red and back again. In red animals, $A^{\mathrm{b}}$ does not show any effect, because these animals do not produce any black pigment. The recessive spotting allele, $S^{\text {s }}$, produces white markings on the body when homozygous, while the dominant allele, $S^{\mathrm{S}}$, produces no, or only very limited white markings [20]. In a study of colour inheritance in 
Table I. Local and translated English names for breeds under study, present-day census-sizes of breeding purebred females and characteristic colour patterns of the breeds.

\begin{tabular}{|c|c|c|}
\hline & $\begin{array}{l}\text { Census } \\
\text { size }\end{array}$ & $\begin{array}{l}\text { Characteristic } \\
\text { colour pattern }\end{array}$ \\
\hline \multicolumn{3}{|l|}{ Danish breeds } \\
\hline $\begin{array}{l}\text { Danish Jersey*, Dansk jersey } \\
\text { Danish Shorthorn, Dansk korthorn } \\
\text { Jutland Breed, Jydsk kvæg } \\
\text { Danish Black-Pied } 1965^{*} \text {, } \\
\text { Sortbroget dansk malkerace } \\
\text { Red Danish } 1970^{*}, \text { Rød dansk malkerace }\end{array}$ & $\begin{array}{r}10000 \\
190 \\
200\end{array}$ & $\begin{array}{l}\text { Solid brown } \\
\text { Dark red } \\
\text { Black pied, Dun pied } \\
\text { Black pied } \\
\text { Solid dark red }\end{array}$ \\
\hline \multicolumn{3}{|l|}{ Finnish breeds } \\
\hline $\begin{array}{l}\text { Western Finncattle, Länsisuomenkarja } \\
\text { Finnish Ayrshire, Suomen ayrshire } \\
\text { Finnish Holstein-Friesian, } \\
\text { Suomen holstein-friisiläinen }\end{array}$ & $\begin{array}{r}5000 \\
280000\end{array}$ & $\begin{array}{l}\text { Red-sided } \\
\text { White with black or } \\
\text { red of ears and muzzle } \\
\text { Solid red or Brown } \\
\text { Red and white } \\
\text { Black pied }\end{array}$ \\
\hline \multicolumn{3}{|l|}{ Icelandic breed } \\
\hline Icelandic cattle, Íslenskir nautgripir & 30000 & $\begin{array}{l}\text { Variable, e.g. Brown, Red, } \\
\text { Black, Brindle, many pied }\end{array}$ \\
\hline \multicolumn{3}{|l|}{ Norwegian breeds } \\
\hline $\begin{array}{l}\text { Blacksided Troender and Nordland Cattle, } \\
\text { Sidet Trønder og Nordlandsfe } \\
\text { Doela Cattle, Dølafe } \\
\text { Eastern Red Polled, } \emptyset \text { stlandsk rødkolle } \\
\text { Telemark Cattle, Telemarksfe } \\
\text { Western Fjord Cattle, Vestlandsk fjordfe } \\
\text { Western Red Polled, Vestlandsk rødkolle } \\
\text { Norwegian Cattle, Norsk Rødt Fe (NRF) }\end{array}$ & $\begin{array}{r}1000 \\
130 \\
70 \\
500 \\
300 \\
\\
260 \\
300000 \\
\end{array}$ & $\begin{array}{l}\text { Black-sided } \\
\text { Brown, Brindle, Black, Red } \\
\text { Solid red } \\
\text { Red-sided } \\
\text { Variable, e.g. Black-sided, } \\
\text { Red-sided, Red } \\
\text { Solid red } \\
\text { Red and white, Red } \\
\end{array}$ \\
\hline \multicolumn{3}{|l|}{ Swedish breeds } \\
\hline $\begin{array}{l}\text { Swedish Red Polled, Svensk rödkulla } \\
\text { Swedish Red and White Cattle, } \\
\text { Svensk röd och vit boskap (SRB) } \\
\text { Swedish Black and White Cattle, } \\
\text { Svensk låglandsboskap (SLB) }\end{array}$ & 380000 & $\begin{array}{l}\text { White with black or red } \\
\text { of ears and muzzle } \\
\text { Solid red } \\
\text { Red and white }\end{array}$ \\
\hline
\end{tabular}

* Old type. 
Table II. Colour loci, alleles and phenotypes at selected loci.

\begin{tabular}{lcccccc}
\hline Phenotype & \multicolumn{6}{c}{ Colour loci and alleles } \\
\hline Dominant black & $E$ & $A$ & $S$ & $B R$ & $D$ & $C S$ \\
\hline Recessive black & $E^{\mathrm{D}} /-$ & - & - & - & $D^{\mathrm{D}} /-$ & - \\
Brown & $E^{+} /-$ & $A^{\mathrm{a}} / A^{\mathrm{a}}$ & - & - & $D^{\mathrm{D}} /-$ & - \\
Brindle & $E^{+} /-$ & $A^{\mathrm{b}} /-$ & - & $B R^{\mathrm{br}} / B R^{\mathrm{br}}$ & $D^{\mathrm{D}} /-$ & - \\
Dun dilution & $E^{+} /-$ & $A^{\mathrm{b}} /-$ & - & $B R^{\mathrm{BR}} /-$ & $D^{\mathrm{D}} /-$ & - \\
Red, solid colour & - & - & - & - & $D^{\mathrm{d}} / D^{\mathrm{d}}$ & - \\
Recessive white markings & $E^{\mathrm{e}} / E^{\mathrm{e}}$ & - & $S^{\mathrm{s}} /-$ & - & $D^{\mathrm{D}} /-$ & $C S^{\mathrm{cs}} / C S^{\mathrm{cs}}$ \\
Colour sided & - & - & $S^{\mathrm{s}} / S^{\mathrm{s}}$ & - & - & - \\
\hline
\end{tabular}

$E=$ extension $; A=$ agouti $S=$ spotting $B R=$ brindle $D=$ dun dilution; $C S=$ colour sided

Icelandic cattle, brindle was found to be dominant on a brown background [6]. In addition to the loci and alleles currently studied and observed in the breeds, the recessive silver allele [6] was detected in two animals in the study, both within the Western Fjord Cattle.

The presence or absence of horns is determined by the two alleles $P$ and $p$ at the polled locus, with the $P / P$ and $P / p$ genotypes being polled, and the $p / p$ genotype carrying horns. Some scurred animals have been reported in the Northern Finncattle, Western Finncattle, Blacksided Troender and Nordland Cattle, Telemark Cattle and Western Fjord Cattle breeds, and were lumped with the polled animals in the present study. Scurred animals have been assumed to be heterozygous for the $P$ allele [25], but recent studies cast some doubt on this hypothesis [9].

A pamphlet with description of colour and horn phenotypes (the English and Norwegian version is available from The Nordic Gene Bank for Farm Animals, Agricultural University of Norway) was prepared and used when determining the colour and horn phenotypes of individual animals. Colour and horn phenotypes were recorded at the time of blood collection [12]; however for Swedish Mountain Cattle these phenotypes were obtained at a later date from printed colour photographs. The colour phenotype of each animal was given as a numerical code, which gave the main colour and the colour shade, as well as the presence and extent of white markings, both dominant and recessive. The estimation of gene frequencies for the loci in question was based on the phenotypes/genotypes presented in Tables II and III, where the coat colour alleles necessary for a given colour phenotype to be manifested in an animal are shown.

The square root method was applied [15] for the estimation of colour and horn gene frequencies. However, there were limitations and assumptions applied for allele frequency estimations $[2,6]$. The frequency of the $A^{\mathrm{b}}$ allele cannot be obtained from data where both dominant and recessive black segregate (both alleles $E^{\mathrm{D}}$ and $E^{+}$occur). In the cases where brown or brindle animals were present in a population, the only alleles known at the A-locus 
were those occurring in the brown and brindle animals. The frequency of the $A^{\mathrm{b}}$-allele was in these cases set to 1.0 , which can only be taken as a confirmation of the presence of the $A^{\mathrm{b}}$-allele. Consequently, since the estimation of the allele frequencies at the A-locus is very imprecise, the $A$-locus was not included in the population genetic calculations. Adalsteinsson et al. [2] demonstrated through segregation analysis, some examples of homozygous recessive black animals. In the present paper, we cannot demonstrate any homozygous recessive blacks, because we only worked with one generation. Recessive black animals $\left(A^{\mathrm{a}} / A^{\mathrm{a}} E^{+} /-\right)$therefore cannot be separated from dominant black $E^{\mathrm{D}} /-$. The frequency of $E^{+}$was therefore underestimated to some extent in the present study. Furthermore, colour sided animals were assumed to be epistatic to all S-locus alleles [20] and were included with the $S^{\mathrm{S}} / S^{\mathrm{S}}$ animals (see Tab. III).

To summarise genetic differentiation between the breeds, the random driftbased measure $\mathbf{G}_{\mathrm{ST}}$ [18] was estimated. In addition, from a matrix of pairwise estimates of $\mathbf{D}_{\mathrm{A}}$ genetic distance of Nei et al. [19] a tree showing the genetic relationship of the breeds was constructed using the neighbour-joining algorithm [21]. Significance of the branching pattern of the tree was evaluated using 1000 bootstrap replications of loci. Data analysis was performed using the DISPAN program (T. Ota, Pennsylvanian State University, PA, USA). A Pearson correlation coefficient $(r)$ of the Mantel test for a matrix correspondence $[16,24]$ was computed using the GENETIX program [3] to analyse if a positive correlation existed between the present $\mathbf{D}_{\mathrm{A}}$ genetic distance matrix (Tab. VI) and three $\mathbf{D}_{\mathrm{A}}$ distance matrices derived from ten microsatellites, 19 blood groups and proteins, and a pooled data set including 29 loci [12]. The Mantel test statistics were tested for significance by carrying out 10000 permutations.

\section{RESULTS}

\subsection{Basic allelic data}

The total number of animals studied per breed and the number of animals per observed phenotype are given in Table III. Allele frequencies for coat colour and polled loci, estimated from the data given in Table III, are shown in Table IV. In addition to the loci and alleles shown in Tables III and IV, the silver allele occurred at a frequency of 0.226 in the Western Fjord Cattle.

The five modern breeds in the study, Finnish Ayrshire, Finnish HolsteinFriesian, Norwegian Cattle (NRF), Swedish Black-and-White Cattle (SLB) and Swedish Red-and-White Cattle (SRB), showed no signs of the intermediate allele $E^{+}$at the $E$-locus (see Discussion). They only produce dominant black or recessive red, but not intermediate brown. The only colour gene variability observed in NRF is due to dominant black obtained recently from imported Holstein cattle semen.

The older breeds, however, showed a much more varied picture. The Eastern Finncattle, Western Finncattle and Swedish Mountain Cattle all showed brown colour, and so did four of the older Norwegian breeds (Blacksided Troender and 
Table III. Number of colour and horn phenotypes in the Nordic cattle breeds.

\begin{tabular}{|c|c|c|c|c|c|c|c|c|c|c|c|c|c|c|c|}
\hline \multirow[t]{2}{*}{ Breed } & \multirow[t]{2}{*}{$\mathrm{N}$} & \multicolumn{14}{|c|}{ Number of animals per observed phenotype } \\
\hline & & $E^{\mathrm{D}}$ & $E^{+}$ & $E^{\mathrm{e}} E^{\mathrm{e}}$ & $A^{\mathrm{b}}$ & $S^{\mathrm{S}}$ & $S^{8} S^{s}$ & $B R^{\mathrm{BR}}$ & - & $D^{\mathrm{D}}$ & $D^{\mathrm{d}} D^{\mathrm{d}}$ & $C S^{\mathrm{CS}}$ & $C S^{\mathrm{cs}} C S^{\mathrm{cs}}$ & $P^{\mathrm{P}}$ & $p^{\mathrm{p}} p^{\mathrm{p}}$ \\
\hline Danish Jersey & 41 & 0 & 41 & 0 & 41 & 40 & 1 & 0 & 41 & 41 & 0 & 0 & 41 & 0 & 41 \\
\hline Danish Shorthorn & 40 & 0 & 0 & 40 & 0 & 3 & 37 & 0 & 0 & 40 & 0 & 0 & 40 & 0 & 40 \\
\hline Jutland Breed & 48 & 37 & 11 & 0 & 11 & 0 & 48 & 8 & 3 & 18 & 30 & 0 & 48 & 0 & 48 \\
\hline Danish Black-Pied & 29 & 29 & 0 & 0 & 0 & 0 & 29 & 0 & 0 & 29 & 0 & 0 & 29 & 0 & 29 \\
\hline Red Danish & 40 & 0 & 0 & 40 & 0 & 40 & 0 & 0 & 0 & 40 & 0 & 0 & 40 & 0 & 40 \\
\hline Eastern Finncattle & 31 & 0 & 1 & 30 & 1 & 0 & 0 & 0 & 1 & 31 & 0 & 31 & 0 & 29 & 2 \\
\hline Northern Finncattle & 26 & 26 & 0 & 0 & 0 & 1 & 0 & 0 & 0 & 26 & 0 & 25 & 1 & 26 & 0 \\
\hline Western Finncattle & 41 & 1 & 1 & 39 & 1 & 37 & 2 & 0 & 1 & 40 & 1 & 2 & 39 & 40 & 1 \\
\hline Finnish Ayrshire & 45 & 0 & 0 & 45 & 0 & 0 & 45 & 0 & 0 & 45 & 0 & 0 & 45 & 0 & 45 \\
\hline Finnish Holstein-Friesian & 43 & 43 & 0 & 0 & 0 & 0 & 43 & 0 & 0 & 43 & 0 & 0 & 43 & 0 & 43 \\
\hline Icelandic Cattle & 48 & II & 22 & 15 & 22 & 18 & 30 & 15 & 7 & 48 & 0 & 0 & 48 & 45 & 3 \\
\hline Blacksided Troender & & & & & & & & & & & & & & & \\
\hline and Nordland Cattle & 36 & 30 & 3 & 3 & 3 & 0 & 1 & 0 & 3 & 36 & 0 & 34 & 2 & 36 & 0 \\
\hline Western Fjord Cattle & 39 & 3 & 18 & 18 & 18 & 25 & 3 & 1 & 17 & 22 & 17 & 11 & 28 & 30 & 6 \\
\hline Doela Cattle & 32 & 7 & 16 & 9 & 16 & 22 & 10 & 13 & 3 & 31 & 1 & 0 & 32 & 9 & 23 \\
\hline Eastern Red Polled & 8 & 0 & 0 & 8 & 0 & 8 & 0 & 0 & 0 & 8 & 0 & 0 & 8 & 8 & 0 \\
\hline Telemark Cattle & 29 & 0 & 0 & 29 & 0 & 0 & 0 & 0 & 0 & 29 & 0 & 29 & 0 & 1 & 28 \\
\hline Western Red Polled & 27 & 0 & 7 & 20 & 7 & 25 & 2 & 0 & 7 & 25 & 2 & 0 & 27 & 27 & 0 \\
\hline $\mathrm{NRF}$ & 39 & 10 & 0 & 29 & 0 & 11 & 28 & 0 & 0 & 39 & 0 & 0 & 39 & 0 & 39 \\
\hline Swedish Mountain Cattle & 94 & 72 & 5 & 17 & 5 & 5 & 6 & 1 & 4 & 94 & 0 & 83 & 11 & 94 & 0 \\
\hline Swedish Red Polled & 34 & 0 & 0 & 34 & 0 & 32 & 2 & 0 & 0 & 34 & 0 & 0 & 34 & 34 & 0 \\
\hline SRB & 39 & 0 & 0 & 39 & 0 & 5 & 33 & 0 & 0 & 39 & 0 & 0 & 39 & 0 & 39 \\
\hline SLB & 44 & 44 & 0 & 0 & 0 & 3 & 41 & 0 & 0 & 43 & 0 & 0 & 43 & 0 & 43 \\
\hline
\end{tabular}

$\mathrm{N}=$ Number of animals studied per breed. 
Table IV. Frequencies of coat colour and horn alleles at 7 loci in 22 nordic cattle breeds.

\begin{tabular}{lccccccccc}
\hline Breed & $E^{D}$ & $E^{+}$ & $E^{\mathrm{e}}$ & $A^{\mathrm{b} *}$ & $S^{\mathrm{s}}$ & $B R^{\mathrm{BR}}$ & $D^{\mathrm{d}}$ & $C S^{\mathrm{CS}}$ & $P^{\mathrm{P}}$ \\
\hline Danish Jersey & 0.000 & 1.000 & 0.000 & 1.000 & 0.156 & 0.000 & 0.000 & 0.000 & 0.000 \\
Danish Shorthorn & 0.000 & 0.000 & 1.000 & 0.000 & 0.962 & 0.000 & 0.000 & 0.000 & 0.000 \\
Jutland Breed & 0.521 & 0.479 & 0.000 & 1.000 & 1.000 & 0.478 & 0.791 & 0.000 & 0.000 \\
Danish Black-Pied & 1.000 & 0.000 & 0.000 & 0.000 & 1.000 & 0.000 & 0.000 & 0.000 & 0.000 \\
Red Danish & 0.000 & 0.000 & 1.000 & 0.000 & 0.000 & 0.000 & 0.000 & 0.000 & 0.000 \\
Eastern Finncattle & 0.000 & 0.016 & 0.984 & 1.000 & 0.000 & 0.000 & 0.000 & 1.000 & 0.746 \\
Northern Finncattle & 1.000 & 0.000 & 0.000 & 0.000 & 0.000 & 0.000 & 0.000 & 0.804 & 1.000 \\
Western Finncattle & 0.012 & 0.013 & 0.975 & 1.000 & 0.226 & 0.000 & 0.156 & 0.025 & 0.844 \\
Finnish Ayrshire & 0.000 & 0.000 & 1.000 & 0.000 & 1.000 & 0.000 & 0.000 & 0.000 & 0.000 \\
Finnish Holstein-Friesian & 1.000 & 0.000 & 0.000 & 0.000 & 1.000 & 0.000 & 0.000 & 0.000 & 0.000 \\
Icelandic Cattle & 0.122 & 0.319 & 0.559 & 1.000 & 0.791 & 0.436 & 0.000 & 0.000 & 0.750 \\
Blacksided Troender & & & & & & & & & \\
and Nordland Cattle & 0.592 & 0.119 & 0.289 & 1.000 & 0.167 & 0.000 & 0.000 & 0.764 & 1.000 \\
Western Fjord Cattle & 0.216 & 0.105 & 0.679 & 1.000 & 0.277 & 0.028 & 0.660 & 0.153 & 0.592 \\
Doela Gattle & 0.134 & 0.336 & 0.530 & 1.000 & 0.559 & 0.567 & 0.177 & 0.000 & 0.152 \\
Eastern Red Polled & 0.000 & 0.000 & 1.000 & 0.000 & 0.000 & 0.000 & 0.000 & 0.000 & 1.000 \\
Telemark Cattle & 0.000 & 0.000 & 1.000 & 0.000 & 0.000 & 0.000 & 0.000 & 1.000 & 0.017 \\
Western Red Polled & 0.000 & 0.139 & 0.861 & 1.000 & 0.272 & 0.000 & 0.272 & 0.000 & 1.000 \\
NRF & 0.138 & 0.000 & 0.862 & 0.000 & 0.847 & 0.000 & 0.000 & 0.000 & 0.000 \\
Swedish Mountain Cattle & 0.516 & 0.059 & 0.425 & 1.000 & 0.253 & 0.106 & 0.000 & 0.658 & 1.000 \\
Swedish Red Polled & 0.000 & 0.000 & 1.000 & 0.000 & 0.243 & 0.000 & 0.000 & 0.000 & 1.000 \\
SRB & 0.000 & 0.000 & 1.000 & 0.000 & 0.932 & 0.000 & 0.000 & 0.000 & 0.000 \\
SLB & 1.000 & 0.000 & 0.000 & 0.000 & 0.965 & 0.000 & 0.000 & 0.000 & 0.000 \\
\hline
\end{tabular}

* The frequency of the $A^{\mathrm{b}}$ allele was set to be 1.0 when present in a population.

Nordland Cattle, Western Fjord Cattle, Doela Cattle and Western Red Polled), one Danish breed (Jutland Breed), and Icelandic Cattle. Brindle colour was found in five of the older breeds (Western Fjord Cattle, Doela Cattle, Jutland Breed, Swedish Mountain Cattle and Icelandic Cattle), dun dilution in five (Western Finncattle, Western Fjord Cattle, Doela Cattle, Western Red Polled and Jutland Breed), and colour sided in six (Eastern Finncattle, Northern Finncattle, Swedish Mountain Cattle, Blacksided Troender and Nordland Cattle, Western Fjord Cattle and Telemark Cattle). The greatest colour variation was found in the Western Fjord Cattle, with variability at six loci, when silver is included. The number of variable loci was four in Doela Cattle, Swedish Mountain Cattle, Western Finncattle and Icelandic Cattle. The $A$-locus is excluded from this comparison. It should be mentioned here that the alleles for colour sided, silver and dun dilution did occur at low frequencies within the Icelandic breed [6], but were not recovered in the present sample. At the polled locus, both the $P^{\mathrm{P}}$ and $P^{\mathrm{P}}$ alleles were observed to segregate in Eastern Finncattle, Western Finncattle, Icelandic Cattle, Western Fjord Cattle, Doela Cattle and Telemark Cattle.

\subsection{Between-population genetic variation}

Gene differentiation $\left(\mathbf{G}_{\mathrm{ST}}\right.$ ) values for single loci ranged from 0.423 (brindle) to 0.832 (polled). The average $\mathbf{G}_{\mathrm{ST}}$ over loci was 0.700 (Tab. V). 
Table V. Coefficient of gene differentiation $\left(\mathrm{G}_{\mathrm{ST}}\right)$ between the 22 nordic cattle breeds.

\begin{tabular}{lc}
\hline Locus & $\mathrm{G}_{\mathrm{ST}}$ \\
\hline extension & 0.685 \\
spotting & 0.656 \\
brindle & 0.423 \\
dun dilution & 0.536 \\
colour sided & 0.796 \\
polled & 0.832 \\
Mean & 0.700 \\
\hline
\end{tabular}

Values of the $\mathbf{D}_{\mathrm{A}}$ genetic distance ranged from zero (between Finnish Holstein-Friesian and Danish Black-Pied 1965) to 0.705 (between Eastern Finncattle and Jutland Breed) (Tab. VI). Values for genetic distances between the Friesian type of breeds (Danish Black-Pied 1965, Finnish Holstein-Friesian and Swedish Black-and-White Cattle) and correspondingly between Danish Shorthorn and the Ayrshire type of breeds (Finnish Ayrshire, NRF and Swedish Red-and-White Cattle) were low.

The relationships between the $\mathrm{D}_{\mathrm{A}}$ genetic distance matrices obtained from the different marker types (the present data in Table VI vs. the previous (1) microsatellite data, (2) the blood group and protein data and (3) the pooled data set) were tested using the Mantel test. The Pearson correlation coefficients $(r)$ of the Mantel test for the matrix correspondence were low, although positive: respective $r$-estimates were $0.122(p=0.161), 0.081(p=0.263)$ and 0.111 $(p=0.200)$.

Breed groups were derived from the topology of the neighbour-joining tree (Fig. 1). Only five nodes were supported by bootstrap values of $50 \%$ or higher. The branching pattern of the tree suggested that three Friesian types of breeds (Danish Black-Pied 1965, Finnish Holstein-Friesian and Swedish Black-andWhite Cattle) were sorted into one subgroup, with the Jutland Breed being an outgroup for this subgroup. Three horned Ayrshire type breeds (NRF, Finnish Ayrshire and Swedish Red-and-White Cattle) and Danish Shorthorn tended to form one subgroup. The third subgroup consisted of red and polled native breeds (Eastern Red Polled, Swedish Red Polled, Western Red Polled and Western Finncattle as an outgroup). Moreover, Eastern Finncattle and Telemark Cattle clustered together, and three northern, polled, typically white breeds (Northern Finncattle, Swedish Mountain Cattle and Blacksided Troender and Nordland Cattle) formed a fifth subgroup. Allocation of Danish Jersey, Red Danish 1970, Icelandic Cattle, Doela Cattle and Western Fjord Cattle into the present subgroups was unclear.

\section{DISCUSSION}

The data presented here show some interesting features. First of all, the older cattle breeds generally show greater variation in observed colours and horn 
Table VI. The matrix of $\mathbf{D}_{A}$ genetic distances between the nordic cattle breeds.

\begin{tabular}{|c|c|c|c|c|c|c|c|c|}
\hline & & $\begin{array}{c}\text { Danish } \\
\text { Jersey }\end{array}$ & 2 & 3 & 4 & 5 & 6 & 7 \\
\hline 2 & Danish Shorthorn & 0.2389 & & & & & & \\
\hline 3 & Jutland Breed & 0.2889 & 0.3066 & & & & & \\
\hline 4 & Danish Black-Pied & 0.2675 & 0.1699 & 0.1831 & & & & \\
\hline 5 & Red Danish & 0.1802 & 0.1342 & 0.4701 & 0.3333 & & & \\
\hline 6 & Eastern Finncattle & 0.4085 & 0.3849 & 0.7048 & 0.5827 & 0.2507 & & \\
\hline 7 & Northern Finncattle & 0.4398 & 0.5604 & 0.6093 & 0.4262 & 0.4262 & 0.2066 & \\
\hline 8 & Western Finncattle & 0.2648 & 0.1790 & 0.4151 & 0.3523 & 0.1386 & 0.1762 & 0.2657 \\
\hline 9 & Finnish Ayrshire & 0.2675 & 0.0032 & 0.3034 & 0.1667 & 0.1667 & 0.4173 & 0.5929 \\
\hline 10 & Finnish Holstein-Friesian & 0.2675 & 0.1699 & 0.1831 & 0.0000 & 0.3333 & 0.5827 & 0.4262 \\
\hline 11 & Icelandic Cattle & 0.2355 & 0.1733 & 0.2519 & 0.2517 & 0.2574 & 0.3298 & 0.3556 \\
\hline 12 & Blacksided Troende & 0.3616 & 0.3996 & 0.5220 & 0.3894 & 0.3440 & 0.1288 & 0.0532 \\
\hline 13 & Western Fjord Cattle & 0.2598 & 0.2277 & 0.2563 & 0.3135 & 0.1996 & 0.2241 & 0.2647 \\
\hline 14 & Doela Cattle & 0.1715 & 0.1539 & 0.1469 & 0.2334 & 0.1870 & 0.3624 & 0.4287 \\
\hline 15 & Eastern Red Polled & 0.3469 & 0.3008 & 0.6367 & 0.5000 & 0.1667 & 0.1907 & 0.2595 \\
\hline 16 & Telemark Cattle & 0.3483 & 0.3023 & 0.6381 & 0.5014 & 0.1681 & 0.0660 & 0.3288 \\
\hline 17 & Western Red Polled & 0.2973 & 0.2568 & 0.4407 & 0.475 & 0.2276 & 0.2437 & 0.3085 \\
\hline 18 & NRF & 0.2129 & 0.0154 & 0.2720 & 0.1180 & 0.1134 & 0.3640 & 0.4658 \\
\hline 19 & Swedish Mountain Cattle & 0.3723 & 0.3593 & 0.4767 & 0.3747 & 0.3256 & 0.1396 & 0.0809 \\
\hline 20 & Swedish Red Polled & 0.3343 & 0.2245 & 0.5546 & 0.4178 & 0.1883 & 0.2124 & 0.2812 \\
\hline 21 & SRB & 0.2299 & 0.0004 & 0.3092 & 0.1724 & 0.1232 & 0.3739 & 0.5494 \\
\hline \multirow[t]{2}{*}{22} & SLB & 0.2400 & 0.1667 & 0.1860 & 0.0029 & 0.3022 & 0.5515 & 0.3950 \\
\hline & & 8 & 9 & 10 & 11 & 12 & 13 & 14 \\
\hline 9 & Finnish Ayrshire & 0.2060 & & & & & & \\
\hline 10 & Finnish Holstein-Friesian & 0.3523 & 0.1667 & & & & & \\
\hline 11 & Icelandic Cattle & 0.1140 & 0.1853 & 0.2517 & & & & \\
\hline 12 & Blacksided Troender & 0.1488 & 0.4280 & 0.3894 & 0.2085 & & & \\
\hline 13 & Western Fjord Cattle & 0.0547 & 0.2536 & 0.3135 & 0.1403 & 0.1615 & & \\
\hline 14 & Doela Cattle & 0.1447 & 0.1730 & 0.2334 & 0.0559 & 0.2957 & 0.1050 & \\
\hline 15 & Eastern Red Polled & 0.0513 & 0.3333 & 0.5000 & 0.1964 & 0.1773 & 0.1778 & 0.2755 \\
\hline 16 & Telemark Cattle & 0.2574 & 0.3348 & 0.5014 & 0.4059 & 0.2575 & 0.2720 & 0.3465 \\
\hline 17 & Western Red Polled & 0.0245 & 0.2829 & 0.4375 & 0.1286 & 0.1736 & 0.0863 & 0.1851 \\
\hline 18 & NRF & 0.1600 & 0.0252 & 0.1180 & 0.1546 & 0.3327 & 0.1862 & 0.1257 \\
\hline 19 & Swedish Mountain Cattle & 0.1270 & 0.3858 & 0.3747 & 0.1510 & 0.0133 & 0.1427 & 0.2371 \\
\hline 20 & Swedish Red Pol led & 0.0313 & 0.2512 & 0.4178 & 0.1332 & 0.1635 & 0.1530 & 0.2284 \\
\hline 21 & SRB & 0.1705 & 0.0058 & 0.1724 & 0.1706 & 0.3907 & 0.2197 & 0.1485 \\
\hline \multirow[t]{2}{*}{22} & SLB & 0.3263 & 0.1696 & 0.0029 & 0.2401 & 0.3621 & 0.2885 & 0.2149 \\
\hline & & 15 & 16 & 17 & 18 & 19 & 20 & 21 \\
\hline 16 & Telemark Cattle & 0.3116 & & & & & & \\
\hline 17 & Western Red Polled & 0.0609 & 0.3725 & & & & & \\
\hline 18 & NRF & 0.2801 & 0.2815 & 0.2453 & & & & \\
\hline 19 & Swedish Mountain Cattle & 0.1589 & 0.2661 & 0.1535 & 0.2994 & & & \\
\hline 20 & Swedish Red Polled & 0.0217 & 0.3333 & 0.0366 & 0.2129 & 0.1363 & & \\
\hline 21 & SRB & 0.2899 & 0.2913 & 0.2488 & 0.0135 & 0.3511 & 0.2162 & \\
\hline 22 & SLB & 0.4688 & 0.4702 & 0.4125 & 0.1085 & 0.3493 & 0.3922 & 0.1671 \\
\hline
\end{tabular}

types and segregating alleles than the modern breeds in the Nordic countries. This was interesting in light of the discussion around the often limited remnants of breeds that have been taken care of during the conservation efforts of the last few decades. In the visible profiles, coat colours and horn forms, the old breeds surpass the modern breeds in terms of genetic variation. Previously, Kantanen [12] found that also mean microsatellite-based unbiased expected heterozygosities and the mean number of microsatellite alleles in the Nordic native cattle breeds were comparable to microsatellite-based estimates for the Nordic commercial breeds. 


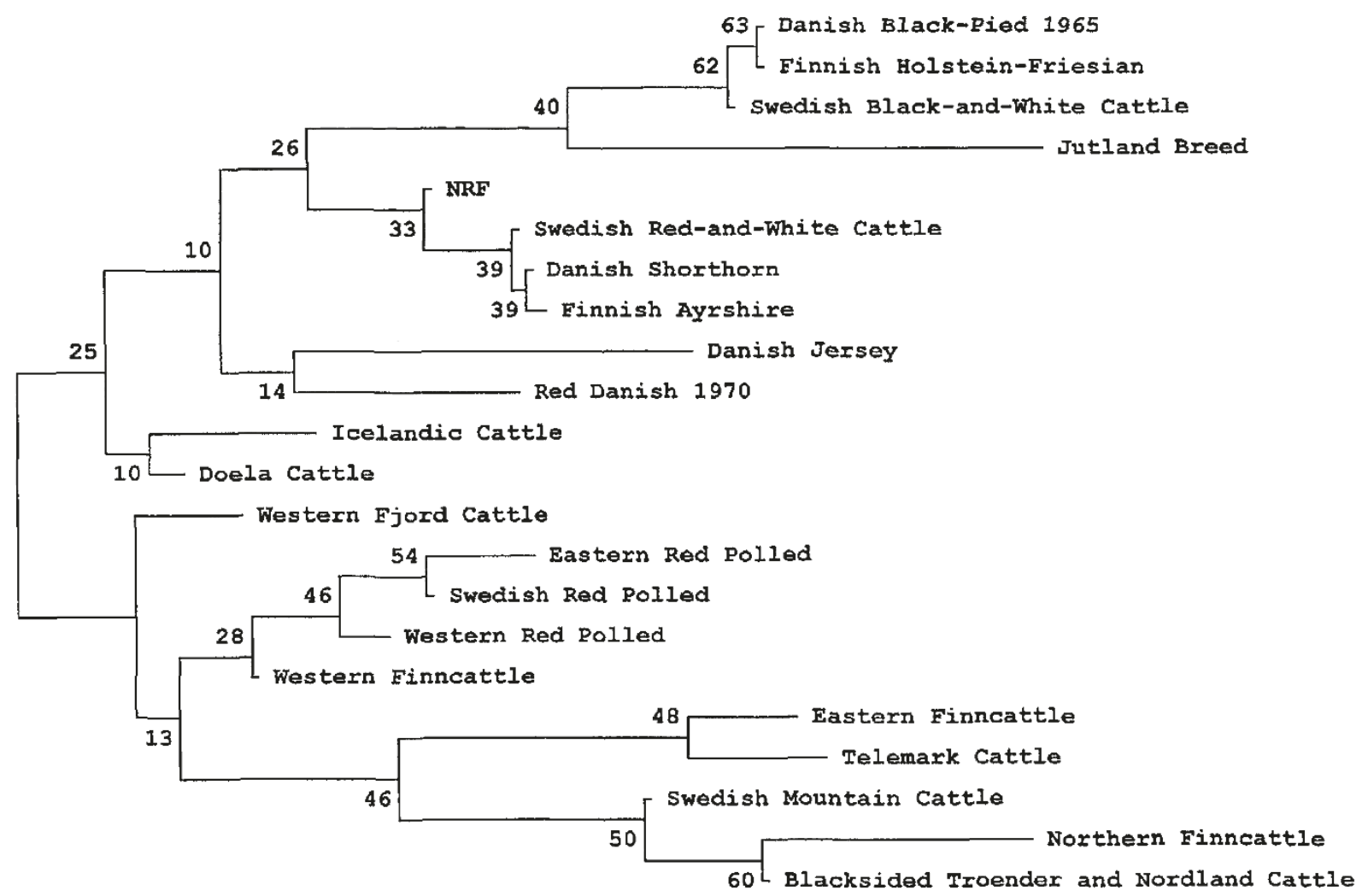

Figure 1. The unrooted neighbour-joining-tree constructed from $\mathrm{D}_{\mathrm{A}}[19]$ genetic distances showing the relationships between $22 \mathrm{Nordic}$ cattle breeds based on coat colours and horn types. Node numbers are percentage bootstrap values from 1000 replicates of resampled loci. 
As presented in the tree (Fig. 1), none of the bootstrap values exceeded an occurrence of $70 \%$, which would suggest a branching order at the $95 \%$ probability level [11]. The low bootstrap values indicate that the pattern of breed clustering was not sufficiently robust and may be explained by an inadequate number of the studied loci.

The Mantel test revealed a poor concordance between the results of genetic relationships between the nordic cattle breeds presented in this study and in a previous study on molecular genetic markers [12]. Compared to the molecular marker data, inter-breed similarities and differences at the genes for coat colours and horns appear to reflect the origins of the Nordic breeds rather poorly. The current branching pattern (Fig. 1) agrees, however, with similarities in observable phenotypic characters between the breeds and to some extent with the previous grouping of the north European cattle breeds derived from the analysis of blood groups, milk proteins, serum proteins and microsatellites [12]. The results may therefore have some value in programs for conservation of rare native cattle breeds through intercrossing schemes. Both the current and previous [12] data sets indicate genetic similarity between Ayrshire type of breeds, between the Friesian type of breeds and between the three mainly white native breeds, Northern Finncattle, Swedish Mountain Cattle, Blacksided Troender and Nordland Cattle. As also suggested by the previous study, the commercial Ayrshire-based and Friesian-based breeds are found to have diverged from most of the Nordic native breeds. Moreover, sorting of Western Fjord Cattle and Doela Cattle into any subgroups is unclear in both studies. However, some dissimilarities in the results of these two studies can be found. The molecular data indicate a close genetic relationship between the northernmost indigenous breeds (Eastern, Northern and Western Finncattle, Swedish Mountain Cattle, Blacksided Troender and Nordland Cattle and Icelandic Cattle), but the present data rather suggests a more close grouping of Western Finncattle with the indigenous breeds from Southern Scandinavia and that of Eastern Finncattle with the Norwegian horned red-sided Telemark Cattle. The molecular genetic study [12] implied grouping of Telemark Cattle with native breeds from southern Scandinavia (Eastern Red Polled and Swedish Red Polled). An additional discordance with the molecular marker data observed here is the close genetic relationship of Danish Shorthorn to the Ayrshire type of breeds and divergence of the Jutland Breed from the subgroup of the Friesian-type of breeds.

As indicated by the mean $\mathbf{G}_{\mathrm{ST}}$ estimate presented in Table V, $70 \%$ of genetic variation was due to breed differences. The subdivision among the north European breeds at the genes for coat colour and horns can be interpreted to be very great, when compared to that typically found among cattle breeds at molecular genetic markers. According to Kantanen [12] mean $\mathbf{G}_{\mathrm{ST}}$ across Nordic cattle breeds was 0.114 at 10 microsatellite loci and 0.130 at 10 codominant blood group and protein loci. In the past, several north European cattle breeds were standardised to characteristic colour type and existence of horns. Furthermore, breeding goals in phenotypic characters have varied from breed to breed. Therefore, not only genetic drift but also selection has been operating at genes for coat colour and horns. This explains the great differentiation among north European cattle breeds and observed discrepancies between the distance 
matrices and the breed groupings derived from the two different marker data sets (the present data vs, the molecular marker data).

Icelandic Cattle are known to have been isolated from other cattle populations for more than 1000 years ([12] and references within) and in contrast to several other cattle breeds, they have not been standardised to any specific colour type. The lack of man-directed selection explains the relatively high phenotypic and genetic variation observed in Icelandic Cattle at the genes for coat colour. This finding of a high level of genetic variation in Icelandic Cattle disagrees with the result presented in the study Kantanen [12]. Compared to several other north European cattle breeds, Icelandic Cattle showed a reduced level of genetic variation at microsatellite loci. In addition to Icelandic Cattle, Western Fjord Cattle and Doela Cattle were found in the present study to display a high level of diversity, which could reflect their historical origin. The study of interbreed genetic variation of north European cattle breeds based on molecular marker data [12] tentatively suggested an admixtured origin for these Norwegian breeds.

The dominance and epistatic relationships in inheritance of coat colours yield that some allelic variation may have remained undetectable when the genetic profile of an animal was assigned for a corresponding phenotype (see materials and methods). However, by following assumptions and limitations $[2,6]$ in the assignment of genetic profiles of animals, we were able to obtain frequencies for the $E$ alleles in Icelandic Cattle comparable to those presented by Adalsteinsson et al. [2], who based their calculations on a large sample of Icelandic Cattle (2095 cows) and progeny information. In contrast, in the present study the estimation of allele frequencies at the agouti locus was imprecise, consequently the alleles at the agouti locus were excluded from data analysis. Our breed sample for the Icelandic Cattle suggested the absence of the non-agouti $A^{\text {a }}$ allele, whereas the frequency of the allele in Icelandic Cattle was previously estimated to be 0.075 [2]. The frequency of the $A^{\mathbf{b}}$ allele may however be very high in european breeds which show brown or brindle colours [2]. The Jersey breed has been postulated to be homozygous for the $A^{\mathrm{b}}$ allele [22]. On the basis of the existence of the $A^{\mathrm{b}}$ allele, present breed samples suggest a separation of the northernmost indigenous cattle breeds (Eastern Finncattle, Western Finncattle, Icelandic Cattle, Blacksided Troender and Nordland Cattle and Swedish Mountain Cattle) from the native breeds of southern Scandinavian origin (Danish Black-Pied 1965, Red Danish 1970, Eastern Red Polled, Telemark Cattle and Swedish Red Polled).

The Brindle colour can only be observed on brown background [6]. Thus we assume that the total number of brindle and non-brindle animals cannot exceed that of $E^{+}$animals. In this study, brindle animals occurred only in the samples of the Jutland Breed, Icelandic Cattle, Western Fjord Cattle, Doela Cattle and Swedish Mountain Cattle. Blacksided Troender and Nordland Cattle are genetically related to Icelandic Cattle and Swedish Mountain Cattle [12]. Brindle animals occur at a low frequency in Blacksided Troender and Nordland Cattle, but are not, however, among the sampled animals of this breed. To our knowledge, no brindle animals have been observed in matings of NRF to brown animals in Norway, which have been quite common during the topcrossing of NRF into the old Norwegian breeds. This implies that the brindle allele is either rare or absent in NRF. 
The two-locus hypothesis presented in [2] suggests that the alleles $A^{\mathrm{a}}$ and $A^{\mathrm{b}}$ at the agouti locus are only able to express their effect (black or brown colour, respectively) in $E^{+} /-$genotypes at the extension locus. In our breed samples, no brown or black animals were found in Danish Shorthorn, Red Danish 1970, Finnish Ayrshire or Swedish Red-and-White Cattle suggesting that only the $E^{\mathrm{e}}$ allele is segregating at the extension locus. The genotypic combination $E^{+} /-$ and $A^{\mathrm{b}} /-$ is therefore not expected (brown colourtype), but $A^{\mathrm{b}}$ can exist in these breeds since the $E^{\mathrm{e}} / E^{\mathrm{e}} A^{\mathrm{b}} / A^{\mathrm{a}}$ genotype produces a red coat colour [2]. In the present study, Danish Black-Pied 1965, Finnish Holstein-Friesian and Swedish Black-and-White Cattle altogether had 116 animals scored, with no red, brown or brindle occurring. This suggests that (1) either the $E^{+}$allele is absent or (2) if it is present the $A^{\mathrm{b}}$ allele is absent or (3) both alleles are absent. We assume that the black-and-white breeds (Danish Black-Pied 1965, Finnish Holstein-Friesian and Swedish Black-and-White Cattle) only have the $E^{\mathrm{D}}$ allele (see also [22]) since the black-and-white breeds show complete dominance of black in crosses with all other breeds. If the colour of these breeds were recessive black, crossing with Jersey would produce brown colour, not black, since the Jersey carries the $A^{\mathrm{b}}$ allele in a homozygous form [22] and $A^{\mathrm{b}}$ is epistatic to $E^{+}$consequently showing its effect. This would have been shown clearly in Denmark where crosses between Friesian and Jersey have often been carried out. The $E^{\mathrm{e}}$ allele occurs at a very low frequency in black-and-white breeds, because red animals are very rarely born in these populations in Nordic. countries.

The presence of polledness in some of the Nordic countries seems to have a long history. Skulls of polled animals were found in excavations from 12 th century cultural layers in Iceland (see [1]). The trait must have arrived to Iceland from Norway ([12] and references within), so it also has a long history there, and probably in Finland and northern Sweden as well. In Lund, in the southernmost part of Sweden, all skulls of cattle found in cultural layers from the period 1020 1400, carried horns [5]. Polled animals were therefore absent, or very rare, in this area at that time. Today, however, polledness occurs with high frequency within the old breeds in Finland, Sweden, Norway and Iceland, while no polled animals occur in the Danish breeds, nor in the samples of the modern Finnish Ayrshire, Finnish Holstein-Friesian, Swedish Red-and-White Cattle, Swedish Black-and-White Cattle and NRF breeds in the present study. Hallander [10] has pointed out that these older breeds with many polled animals may originate from polled breeds in northern Russia.

\section{ACKNOWLEDGEMENTS}

The data in the present study were collected as part of a Nordic project: Genetic profiles of cattle breeds in the Nordic countries. Thanks are due to Nina Hovden-Sæther, Claes Göran Fristedt and Mensur Vegara for help in data collection, to Sigridur Bjarnadottir for access to unpublished data on cattle colour and to Miika Tapio for help in statistical expertise. We thank two anonymous reviewers for comments on an earlier draft of this manuscript. Funding of the project was provided by the Nordic Council of Ministers. 


\section{REFERENCES}

[1] Adalsteinsson S., Uppruni islenskra husdyra (The origin of Icelandic farm animals), in: Johannesson F.F. (Ed.), Islensk thjodmenning I (The National Culture of Iceland I), Thjodsaga, Reykjavik, 1987, pp. 31-46 (In Icelandic).

[2] Adalsteinsson S., Bjarnadottir S., Våge D.I., Jonmundsson J.V., Brown coat color in Icelandic cattle produced by the loci extension and agouti, J. Hered. 86 (1995) 395-398.

[3] Belkhir K., Borsa P., Goudet J., Chikhi L., Bonhomme F., GENETIX, logiciel sous Windows ${ }^{\text {TM }}$ pour la génétique des populations. Laboratoire génome et populations, Université de Montpellier II, Montpellier, Version 3.3 (1996).

[4] Berge S., Storfefarger (Cattle colours), Agricultural University of Norway, Animal Production Department, Report No. 201, 1965 (In Norwegian).

[5] Bergquist H., Lepiksaar J., Animal skeletal remains from medieval Lund. Archaeology of Lund. Studies in the Lund excavation material. I, Museum of Cultural History, Lund, Sweden, 1957.

[6] Bjarnadottir S., Nedarving av farge hos islandsk storfe. Hovedoppgave, Institutt for husdyrfag, Norges Landbrukshøgskole (Inheritance of colour in Icelandic cattle), MSc Thesis, Animal Production Department, Agricultural University of Norway, 1993, 107+11 p. (In Norwegian).

[7] Bogart R., Ibsen H.L., The relation of hair and skin pigmentation to colour inheritance in cattle, with some notes on guinea pig hair pigmentation, J. Genet. 35 (1937) 31-59.

[8] Gjelstad B., Storfe (Cattle), in: Gjelstad B., Kolstad N., Maijala K. (Eds.), Husdyr i Norden (Farm animals in the Nordic countries), Landbruksforlaget, Oslo, 1993, pp. 46-72 (In Norwegian).

[9] Georges M., Drinkwater R., King T., Mishra A., Moore S.S., Nielsen D., Sargeant L.S., Sorensen A., Steele M.R., Shao X., Womack J.E., Hetzel J., Microsatellite mapping of a gene affecting horn development in Bos taurus, Nat. Genet. 4 (1993) 206-210.

[10] Hallander H., Svenska lantraser (Swedish landraces). Bokförlaget Blå Ankan, Veberöd, 1989 (In Swedish).

[11] Hillis D.M., Bull J.J., An empirical test of bootstrapping as a method for assessing confidence in phylogenetic analysis, Syst. Biol. 42 (1993) 182-192.

[12] Kantanen J., Genetic diversity of domestic cattle (Bos taurus) in North Europe. PhD Thesis, University of Joensuu, Joensuu, Publications in Sciences No. 52, 1999,49 p. + App.

[13] Klungland H., Våge D.I., Gomez-Raya L., Adalsteinsson S., Lien S., The role of melano-stimulating hormone (MSH) receptor in bovine coat color determination, Mamm. Genome 6 (1995) 636-639.

[14] Lauvergne J.-J., Génétique de la couleur du pelage des bovins domestiques, Biblio. Genet. 20 (1966) 1-68.

[15] Li C.C., First Course in Population Genetics, The Boxwood Press, Pacific Grove, California, 1976.

[16] Mantel N., The detection of disease clustering and a generalized regression approach, Cancer Res. 27 (1967) 209-220.

[17] Mountjoy K.G., Robbins L.S., Mortrud M.T., Cone R.D., The cloning of a family of genes that encode the melanocortin receptors, Science 257 (1992) 1248-1251.

[18] Nei M., Analysis of gene diversity in subdived populations, Proc. Nat. Acad. Sci. USA 70 (1973) 3321-3323. 
[19] Nei M., Tajima F., Tateno Y., Accuracy of estimated phylogenetic trees from molecular data, J. Mol. Evol. 19 (1983) 153-170.

[20] Olson T.A., Willham R.L., Inheritance of coat coloration and spotting patterns of cattle. A Review, Res. Bull. 595 Ames, Iowa (1982) 147-176.

[21] Saitou N., Nei M., The neighbor-joining method: a new method for reconstructing phylogenetic trees, Mol. Biol. Evol. 4 (1987) 406-425.

[22] Searle A.G., Comparative genetics of coat colour in mammals, Logos Press Limited, London, 1968.

[23] Simon D.L., Buchenauer D., Genetic diversity of European livestock breeds, EAAP Publication No. 66, Wageningen Pers, 1993.

[24] Smouse P.E., Long J.C., Sokal R.R., 1986. Multiple regression and correlation extensions of the Mantel test of matrix correspondence, Syst. Zool. 35 (1986) $627-632$.

[25] White W.T., Ibsen H.L., Horn inheritance in Galloway-Holstein cattle crosses, J. Genet. 32 (1936) 33-49.

[26] Wright S., Color inheritance in mammals, J. Hered. 8 (1917) 521-527.

To access this journal on line: www.edpsciences.org 